\title{
Üç Kuşak Kadınların Doğum Deneyimleri ve Doğum Algılarının İncelenmesi: Batı Anadolu Kırsalı Örneği
}

Investigation of the Birth Experiences and Birth Perceptions of Three Generations of Women: Rural Example of Western Anatolia

\section{Dilek HACIVELIOGĞLU ${ }^{1}$, Nursen BOLSOY ${ }^{2}$}

\section{Öz}

Birçok toplumda yaşamın doğal bir parçası olarak algılanan doğum, kadınlar için önemli bir deneyimdir. $\mathrm{Bu}$ deneyimin hem kadına hem de çevresine olumlu veya olumsuz yansımaları olabilmekte ve kuşaktan kuşağa aktarılarak toplumun doğum algısını etkileyebilmektedir. $\mathrm{Bu}$ çalışmada kırsalda yaşayan, bebek patlaması kuşağı, x kuşağı ve y kuşağına dahil olan kadınların doğum deneyimlerinin, doğum şekline bakış açılarının ve bunların kuşaklararası ilişkisinin incelenmesi amaçlanmıştır. Araştırma kırsalda yaşayan, doğum yapmış 101 kadın ile yürütülmüştür. Veriler araştırmacılar tarafindan hazırlanan anket formu ile toplanmıştır. Zaman içinde kadınlarda üreme sağlığı, obstetrik özellikler ve doğumlarıyla ilgili kararlarda söz sahibi olmaları açısından olumlu gelişmeler olduğu saptanmıştır. Öte yandan kadınların doğum korkusu ve negatif doğum ağrısı algıları artmış, normal vajinal doğum oranları azalmış, sezaryen doğum tercihine eğilim artmıştır.

Anahtar Kelimeler: Doğum, Doğum alg1s1, Doğum deneyimi, Ebelik, Kuşaklararası.

\begin{abstract}
Birth, which is perceived as a natural part of life in many societies, is an important experience for women. This experience can have positive or negative repercussions for both women and their environment, and can be transmitted from generation to generation to affect the perception of birth in society. The aim of this study was to examine the birth experiences, perspectives of birth type and the intergenerational relationship of women living in rural areas that belong to baby boomer generation, $x$ generation and $y$ generation. The study was conducted with 101 women who had given birth in rural areas. The data were collected by a questionnaire prepared by the researchers. Over time, it has been found that there are positive developments in terms of having a say in the decisions about reproductive health, obstetric characteristics and births. On the other hand, women's perceptions of birth fear and negative birth pain increased, normal vaginal delivery rates decreased, and the tendency to cesarean delivery preference increased.
\end{abstract}

Keywords: Birth, Birth experience, Intergenerational, Midwefery, Perception of birth.

${ }^{1}$ Doktora Öğrencisi, Ebelik, Manisa Celal Bayar Üniversitesi, Sağlık Bilimleri Enstitüsü, Ebelik Anabilim Dalı, dyakti@gmail.com, ORCID: 0000-0003-4806-6888

${ }^{2}$ Dr. Öğr. Üyesi, Kadın Sağlığı ve Hastalıkları Hemşireliği, Manisa Celal Bayar Üniversitesi, Sağlık Bilimleri Fakültesi Ebelik Bölümü, nursenbolsoy@gmail.com, ORCID: 0000-0001-7035-6342 


\section{GIIRIŞ}

Birçok toplumda hayatın olağan parçası olarak görülen doğum, normal fizyolojik bir olay olmakla birlikte bazen içinde riskler de barındırabilen yaşamın en önemli deneyimlerinden biridir. Kadın doğası gereği genellikle normal vajinal doğum gerçekleşmesi mümkün olsa da gebelik boyunca kadında bir takım psikolojik değişiklikler ortaya çıkmakta, özellikle doğum öncesi ve sonrası dönemde yaşanan kaygı durumu kadınları olumsuz olarak etkilemektedir. $^{1} \quad$ Obstetrik gereklilikler dışında, doğumla ilgili bilinmezlikler, sağlık personeline karşı güvensizlik, bebeğin ya da annenin zarar göreceği düşüncesi, ölüm korkusu, epizyotomi ya da yırtılma düşüncesi ve doğum hakkında alınan negatif duyumlar doğum korkusuna neden olabilmekte, korku da sezaryen doğumlara eğilime katk1 sağlamaktadır. Özellikle doğum süreci hakkında bilgi sahibi olmayan kadınlarda doğum korku skorunun yüksek olduğu, doğum korkusu nedeniyle sezaryen doğumların tercih edildiği ve kadının doğum ile ilgili bilgisi arttıkça sezaryen tercihlerinin azaldığ1 belirtilmektedir. ${ }^{2}$ Ülkemizde sezaryen oranlarının yıllar içinde arttığ1 görülmektedir. Sezaryen doğum oran1 1993 yılında \%7 iken zaman içinde hızlı yükselme göstererek 2013 yılında \%48, 2018 y1lında ise $\% 52$ olmuştur. ${ }^{3}$ Sağllk profesyonellerinin gebelerin ihtiyaç duyduğu desteği sağlaması, komplikasyonlu doğumlar yaşansa bile pozitif doğum deneyimi yaşanmasını sağlayabilmektedir., 5, ${ }^{4}$ Dolayısıyla obstetrik gereklilikler dışında sezaryen etkenlerinin destekleyici bakım ve bilgilendirilme ile azalmasını sağlamak açısından da kadının doğumla ilgili deneyim, alg1 ve beklentilerinin bilinmesi önem taşımaktadır.

Gebe ve ailesi için anlamlı bir olay olan doğum eylemi genellikle kadın belleğinde yer etmekte ve ayrıntıları ile hatırlanmaktadır. ${ }^{6}$ Öte yandan doğum sadece kadını etkilemekle kalmayıp aynı çevrede olan diğer kadınlara da yansıması olabilmektedir. Kadında kalıcı olumsuz sonuçlara neden olan travmatik deneyimler kuşaklararası aktarımla da toplumun doğum algis1 ve deneyimlerini etkileyebilmektedir. $^{7}$

\section{Kuşak Kavramı ve Sınıflandırılması}

Kuşak (jenerasyon) aynı zaman aralıklarında doğan, yaşadıkları toplumun sosyal, kültürel, ekonomik ve politik durumundan kaynaklı farklılıkları barındıran, benzer değer ve önceliklere sahip olan insan topluluğunu tanımlamak için kullanılan bir kavramdır. ${ }^{8}$ Aynı kuşaktan olan kişilerin genellikle benzer davranışları sergilediği, daha sonraki kuşaklarla yaşam şekli ve hayata bakış açısı yönünden farklılık gösterdiği, kuşak farklılığının algılama değişikliklerinin oluşmasında etken olduğu belirtilmektedir. $\mathrm{Bu}$ çalışmada incelenen kuşakların yaş aralığı araştırmanın yapıldığı yerde yaşayan ve doğum yapmış olan kadınların yaş aralığı da dikkate alınarak literatür doğrultusunda seçilmiştir. ${ }^{8,9}$ Kuşak sınıflandırılması:

\section{Baby Boomer (Bebek Patlamasi [BP]) Kuşağı (1946-1965)}

İkinci dünya savaşından sonra doğum oranının arttığı yıllarda doğan bu kuşak, radyonun altın çağını yaşamıştır. Yaşanan nüfus patlaması nedeniyle bu ismi alan kuşak ayrıca aynı evde hem çocuklarına hem de daha sonra yaşlanan ebeveynlerine baktıkları için 'sandviç kuşağı' olarak da bilinmektedir. ${ }^{9}$

\section{Kuşağı (1966-1980)}

Türkiye'de 'Geçiş Dönemi Çocukları' şeklinde de tanımlanan x kuşağı dünyadaki önemli büyük değişimleri yaşamış, patlama kuşağına kıyasla bireysel davranan, bilgi almada değişik medya kanallarını tercih eden bir kuşak olarak tanımlanmaktadır. ${ }^{8}$

\section{Y Kuşağı (1981-2000)}

'İnternet kuşağı', 'Echo-Boomers', 'Millenial' ve 'Nexters' olarak da ifade edilmektedir. İnternetin olduğu yıllarda doğan bu kuşağın sosyal ve iş hayatında yeni bir dönüşüm dalgası oluşturduğu ve önceki kuşaklardan farklı olarak günlük hayatta farklı kültürdeki kişilerle çok fazla etkileşim içinde olduğu belirtilmektedir. Y kuşağı modern 
teknolojili ve tüketim odaklı bir anlayışla büyümüştür. ${ }^{9}$

\section{Literatür İncelemesi}

Literatürde kadınları gebelik ve doğum açısından kuşaklararası inceleyen çalışmaların sınırlı olduğu görülmektedir. Kay ve arkadaşları (2017), iki kuşaktaki kadınların doğum anlayışları ile ilgili hikâyelerini; Sharp ve arkadaşları (2014) ise doğum sonu kanama riskinin kuşaklararası aktarımını incelemişlerdir. ${ }^{10}{ }^{11}$ Ayrıca preterm doğum, genç gebelik, olumsuz doğum sonuçları ve anne doğum kilosu ile bebek doğum kilosu ilişkisi açısından kuşaklararası inceleme yapılan çalışmalar olduğu görülmektedir. ${ }^{12-14}$
Ülkemizde kuşaklararası farklılıkların incelenmesine yönelik yapılan araştırmaların daha çok iş yaşamı ve sosyal bilimler alanında olduğu görülmektedir. ${ }^{8}{ }^{9}$ Değişik yönleri ile doğum deneyimi ve algıları üzerine yapılmış çalışmalara bakıldığında ise genellikle kent merkezi ve hastanelerde yapılmış araştırmalar olduğu ve farklı kuşaktan kadınların doğum deneyimlerinin incelendiği çalışmalara rastlanmadığ 1 görülmektedir. ${ }^{1,4,5,15,16} \mathrm{Bu}$ çalışmada kırsalda yaşayan, BP kuşağı, x kuşağı ve y kuşağına dâhil olan kadınların doğum deneyimlerinin, doğum şekline bakış açılarının ve bunların kuşaklararası ilişkisinin incelenmesi amaçlanmıştır.

\section{MATERYAL VE METOT}

\section{Araştırmanın Tipi}

Tanımlayıcı tipte olan bu çalışma Uşak ilinin bir köyünde gerçekleştirilmiştir.

\section{Araştırmanın Evren ve Örneklemi}

Araştırmanın evrenini köyde yaşayan ve doğum yapmış tüm kadınlar $(\mathrm{N}=104)$ oluşturmuştur. Örneklem seçim yöntemine gidilmemiş, tüm evrene ulaşılmaya çalışılmıştır. Köy sağlık evine hizmet amaciyla gelen ya da ev ziyaretleri ile ulaşılan, herhangi bir iletişim ve hafiza sorunu olmayan, gönüllü olarak araştırmaya katılmayı kabul eden kadınlar $(\mathrm{n}=101)$ örneklemi oluşturmuştur.

\section{Veri Toplama Araçları}

Araştırmada, katılımcının tanımlayıcı, obstetrik özellikleri ve doğum deneyimini sorgulayan, araştırmacılar tarafından literatür doğrultusunda oluşturulan anket formu kullanılmıştır. Araştırmaya katılmaya gönüllü kadınlara çalışma hakkında bilgi verilerek sözlü ve yazılı onamları alındıktan sonra yüz yüze görüşme tekniği ile anket formu doldurulmuştur. Görüşmede sadece katılımcı ve araştırmacı olmak suretiyle her bir görüşme 25-30 dakika sürmüştür.

\section{Verilerin Değerlendirilmesi}

İstatistiksel analizler için NCSS (Number Cruncher Statistical System) 2007 (Kaysville, Utah, USA) programı kullanılmıştır. Çalışma verileri değerlendirilirken tanımlayıcı istatistiksel metodlar (ortalama, standart sapma, medyan, frekans, oran, minimum, maksimum) kullanılmıştır. Nicel verilerin normal dağılıma uygunlukları KolmogorovSmirnov, Shapiro-Wilk testi ve grafiksel değerlendirmeler ile sınanmıştır. Normal dağılım gösteren üç ve üzeri grupların karşılaştırmalarında One-way Anova Test ve ikili karşılaştırmalarında Bonferroni test; normal dağılım göstermeyen üç ve üzeri grupların karşılaştırmalarında ise Kruskal Wallis test ve ikili karşılaştırmalarında Bonferroni-Dunn test kullanılmıştır. Nitel verilerin karşılaştırılmasında ise Pearson KiKare testi ve Fisher-Freeman-Halton Exact testi kullanılmıştır. Anlamlılık en az $\mathrm{p}<0,05$ düzeyinde değerlendirilmiştir.

\section{Araştırmanın Etik Yönü}

Araştırmanın yapılabilmesi için Manisa Celal Bayar Üniversitesi Sağlık Bilimleri Etik Kurulu'ndan (Karar Tarih/No: 01/08/2018/20.478.486), Uşak İl Sağlık Müdürlügü’nden $\quad(11 / 08 / 2018$ tarihli ve 
$71438662 / 774.99 \quad$ say1l $\quad$ yazı) ve katılımcılardan yazılı izin alınmıştır.

\section{Araştırmanın Sınırlılıkları}

Araştırma, sadece çalışmanın yapıldı̆̆ kırsal bölgedeki kadınların ifadelerini içermektedir. Ayrıca hatırlayamamaktan kaynaklı biaslar söz konusu olabilir.

\section{BULGULAR VE TARTIŞMA}

Bulgular ve tartışmalarının yer aldığı bu bölümde, bulgularımızın tartışmasının yapılabileceği kuşaklararası çalışmaların yetersiz olmasından dolayı tartışmada konu ile ilgili çalışmalardan yararlanılmıştır. Çalışmamızda kadınların doğumları ile ilgili özellikler ilk üç doğumları dikkate alınarak sorgulanmış ve değerlendirilmiştir.

Çalışma 101 kadın ile yapılmıştır. Kadınların yaşları 20 ile 70 arasında değişmekte olup ortalama $46.98 \pm 15.73$ yıldır. Kadınların \%35,6'sını $\quad(\mathrm{n}=36) \quad$ çalışma tarihlerinde yaşı 54 ve üzeri olan BP kuşağı, $\% 26,8$ 'ini $(\mathrm{n}=27)$ yaşı $40-53$ yaş aralığında olan x kuşağı, \%37,6'sını $(n=38)$ yaşı 40'1n altında olan y kuşağı oluşturmaktadır. Kadınların diğer tanımlayıcı özellikleri, obstetrik özellikleri ve değerlendirilmeleri Tablo 1'de verilmiştir.

Kuşaklara göre kadınların eğitim durumları arasında istatistiksel olarak anlamlı farklılık saptanmıştır $(\mathrm{p}=0,001 ; \mathrm{p}<0,01)$; BP kuşaği kadınların eğitim durumlarının okuryazar değil, x kuşağı kadınların ilkokul mezunu, y kuşağı kadınların ise ortaokul ve üzeri olma oranı daha yüksektir. Cumhuriyet'in kuruluşundan itibaren Türkiye eğitim sisteminde uygulanan kademeler arası geçiş politikalarına bakıldığında, 1923-1997 yılları arasında beş y1llık ilkokulun zorunlu olduğu, 1997-2012 yılları arasında zorunlu eğitim süresinin sekiz yıla yükseltildiği görülmektedir. Şu an uygulanmakta olan sistem ise 2012 y1lında uygulamaya konulan, zorunlu eğitimin 12 yıla çıkarıldığı, 4-4-4 olarak bilinen sistemdir. ${ }^{17}$ Çalışmamızda yer alan y kuşağı kadınlarının ilköğretim dönemlerinin sekiz yıllık zorunlu eğitimin uygulandığı zamanlara denk gelmesi eğitim durumlarının ortaokul ve üzeri olma oranlarının yüksekliğini açıklayabilir.
Kadınların toplam gebelik sayıları BP kuşağında 7,25 $\pm 2,52$; x kuşağında 5,63 $\pm 2,36$; y kuşağında $2,89 \pm 1,43$ olarak bulunmuştur. Kuşaklara göre kadınların toplam gebelik sayıları arasında istatistiksel olarak anlamlı farklılık saptanmıştır $(p=0,001 ; p<0,01)$. BP kuşağı ve $\mathrm{x}$ kuşağı kadınların toplam gebelik sayıları, y kuşağı kadınlardan daha yüksektir (sirasiyla $p=0,001 ; p=0,001 ; p<0,01$ ). Refah ve eğitim düzeyinin yükselmesiyle doğurganlık azalmaktadır. Türkiye'de toplam doğurganlık hızının yıllar içerisinde düştüğü, 1990'larda 2,6'ya kadar gerilediği, 2013 y1lında 2,26, 2018'de ise 2,3 olduğu görülmektedir. Önceki yıllara göre fark kapanmaya başlasa da kırsaldaki toplam doğurganlık hızı $(2,8)$ kente göre $(2,2)$ daha yüksektir. Ayrıca, gebeliği önleyici modern aile planlaması yöntemi kullanımı ülkemizde 1988-2018 yılları arasında sürekli olarak artış göstermiştir. ${ }^{3} \mathrm{Bu} 30$ yıllık dönemin de $\mathrm{x}$ kuşağının doğurganlık dönemine denk geldiği görülmektedir. Y kuşağının hala doğurganlık çağında olması ve çalışmanın yapıldığ dönemde tek gebeliğe sahip kadınların bulunması da bu kuşak kadınlarında gebelik sayısının düşük çıkmasında etkili olmuş olabilir.

Kuşaklara göre kadınların toplam düşük sayıları arasında istatistiksel olarak anlamlı farklılık saptanmıştır $(p=0,002 ; p<0,01)$. BP kuşağ1 ve $\mathrm{x}$ kuşağı kadınların toplam düşük sayıları, y kuşağı kadınlardan daha yüksektir (sirasiyla $\mathrm{p}=0,001 ; \mathrm{p}=0,001 ; \mathrm{p}<0,01$ ). Kuşaklara göre kadınların kürtaj sayıları incelendiğinde de kuşaklar arasında istatistiksel olarak anlamlı farklılık saptanmıştır $(p=0,008 ; p<0,01) . X$ kuşağ 1 kadınların kürtaj sayıları, BP kuşağı ve $\mathrm{y}$ kuşağı kadınlardan daha yüksektir (sırasıyla $\mathrm{p}=0,043 ; \mathrm{p}=0,008 ; \mathrm{p}<0.05)$. (Tablo 1$)$. 
Tablo 1. Kadınların Tanımlayıcı ve Obstetrik Özellikleri ve Kuşaklara Göre Değerlendirilmesi

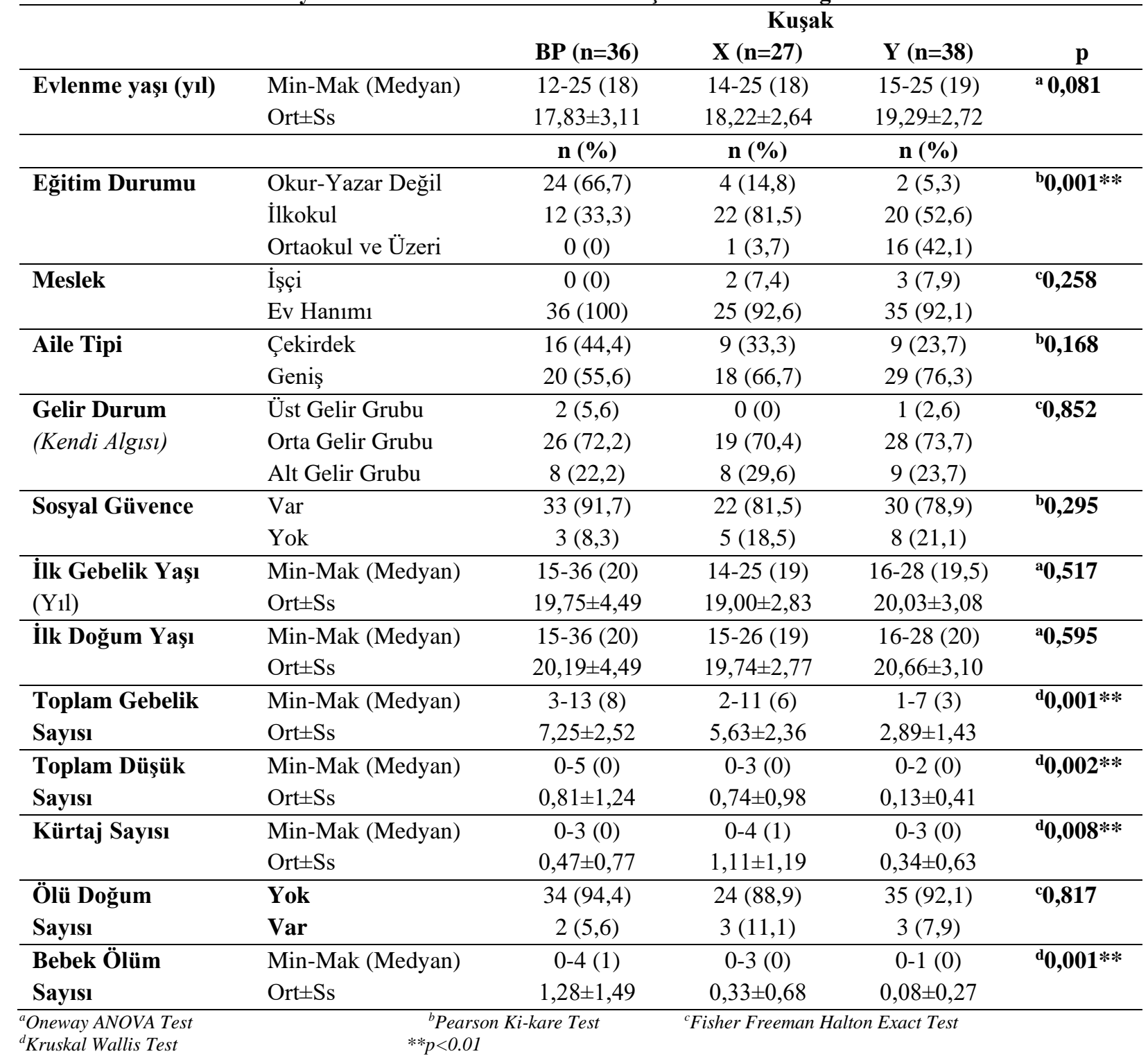

Eğitim düzeyi ve sosyoekonomik düzeyin düşük olması istenmeyen gebeliklerin önemli bir nedenidir. Türkiye Nüfus ve Sağlik Araştırması (TNSA) 2018 verilerine göre, Türkiye'de yaşam boyu yapılan kendiliğinden düşügün ortalama sayıs 0,32 ; isteyerek düşüğün ise $0,21^{\text {' }}$ dir. $^{3}$ Çalışmamızda sadece y kuşağ 1 kadınlarının kendiliğinden düşük ortalaması (0.13) ülke ortalamasının altındadır. Kürtaj oranları ise tüm kuşak kadınlarında ülke ortalamasının üzerinde bulunmuştur (Tablo 1). Ülkemizde 1983 yılında "Nüfus Planlaması Hakkında Kanun' ile yasal olarak kürtajın önü açılmıştır. ${ }^{3}$ Çalışmamızda BP kuşağı kadınlarının üreme çağının kürtajın yasal olmadığı döneme denk gelmesi ve ulaşılabilirliğin kısıtlı olması nedeniyle bu kuşak kadınlarında düşüğün yüksek, kürtajın ise daha az oranda olmasını etkilemiş olabilir. Literatürde istenmeyen gebeliklere yönelik yapılan kuşaklar arası bir çalışma mevcuttur. Liu ve arkadaşlarının (2018), anneler ve genç kızların kuşaklararası kürtaj eğilimini incelemek amacıyla yaptıkları retrospektif kohort çalışmasında, anne kürtajı genç kızlardaki kürtaj için bir risk faktörü olarak tanımlanmakta, riskin anne kürtaj sayısı arttıkça daha belirgin olduğu belirtilmektedir. ${ }^{18}$

Kuşaklara göre kadınların bebek ölüm sayıları arasında istatistiksel olarak anlamlı farklılık saptanmıştır $(\mathrm{p}=0,001 ; \mathrm{p}<0,01) . \mathrm{BP}$ kuşağı kadınların bebek ölüm sayıları, x kuşağ 1 ve y kuşağ 1 kadınlardan daha yüksektir (sirasiyla $\mathrm{p}=0,016 ; \mathrm{p}=0,001 ; \mathrm{p}<0,05$ ). (Tablo 1). Ülkemizde bebek ölüm hızı 1960'lı 
yıllardan itibaren düşmeye başlamış, sağlık sisteminde yapılan düzenlemeler neticesinde 1998-2008 yılları arasında yüzde 48 azalma sağlanmıştır. Özellikle 2003 yılında başlatılan Sağlıkta Dönüşüm Programı düşüşün devam etmesinde etkili olmuştur. ${ }^{19}$ Dolayısıyla BP kuşağında bulduğumuz istatistiksel anlamlılık bu bulgularla uyumludur.

Kadınların gebelik ve doğum sürecine ilişkin özellikleri ve kuşaklararası değerlendirilmeleri Tablo 2'de verilmiştir. BP kuşağının \%33,3'ünde, x kuşağının \%59,3' ünde, y kuşağının ise \%78,9'unda son gebelikler isteyerek planlı gerçekleşmiştir. Kuşaklara göre son gebeliğin isteyerek olma durumları arasında istatistiksel olarak anlamlı farklılık saptanmıştır $(\mathrm{p}=0,001 ; \mathrm{p}<0,01)$; $\mathrm{x}$ kuşağ1 ve $\mathrm{y}$ kuşağ1 kadınlarının son gebeliğinin isteyerek planlı olma oranı, BP kuşağından daha yüksektir. Son yıllarda çeşitli konularda yapılmış çalışmalarda kadın gruplarının özelliklerine göre değişim gösterse de planlı gebeliklerin çoğunlukta olduğu görülmektedir. ${ }^{6,}{ }^{20}$ Plansız gebeliğin sosyoekonomik durum, eğitim ve aile planlaması yöntemi kullanımı gibi faktörlerle ilişkili olduğu bildirilmiştir. ${ }^{20}$ Kara ve arkadaşlarının (2012) hem kırsal hem de kentsel kesimi yansitan, sosyoekonomik faktörler ile gebelik parametreleri arasındaki ilişsinin incelendiği çalışmada da, aylık gelir düzeyi düşük aileden olan gebelerde planlı gebelik $\% 67,4$, aylık gelir düzeyi daha iyi olanlarda $\quad \% 80,9 \quad$ bulunmuştur. $^{21}$ Çalışmamızda BP kuşağı kadınlarının son gebeliklerinde plansız ve eş isteği ile gebe kalma oranlarının yüksek olmasının nedeni; sosyokültürel faktörler, düşük eğitim düzeyi gibi nedenlerle kadınların doğurganlıkları üzerinde söz sahibi olamamaları ve o tarihlerde sağlık hizmetlerine ulaşmada yaşanan kısıtlılıklar olabilir.

BP kuşağı kadınlarının \%5,6's1, $\quad \mathrm{x}$ kuşağının \%51,9'u, y kuşağının ise \%94,7'si doğum öncesi kontrollerine gitmişlerdir. Kuşaklara göre kadınların gebeliklerinde doğum öncesi kontrole gitme oranları arasında istatistiksel olarak anlamlı farklılık saptanmıştır $(p=0,001 ; p<0,01) ; y$ kuşağ 1 kadınlarının gebeliklerinde doğum öncesi kontrole gitme oranları, BP kuşağ 1 ve x kuşağ kadınlarından daha yüksektir (Tablo 2). Doğum öncesi bakım alma; anne yaşı, eğitimi, doğum sırası ve yerleşim yeri ile yakından ilişkilidir. Türkiye'de özellikle 1998 ve 2003 yılları arası doğum öncesi bakım alma durumunda önemli gelişmeler olduğu ve neredeyse tüm kadınları (\%96) kapsadığ1 belirtilmektedir. $^{3}$ Buna paralel olarak çalışmamızda kadınların doğum öncesi kontrole gitme oranları da kuşaklararası sırası ile artma göstermektedir. Çalışmanın yapıldığı ilde 2009 yılında aile hekimliği sistemine geçilmesiyle gebelik izlemlerinin performansa dayalı hale gelmesinin, üreme dönemleri bu yıllara denk gelen y kuşağındaki kadınlarda doğum öncesi bakım alma oranlarına yansımış olduğu görülmektedir.

Kadınlar doğumlarının sonuçlanma şekline karar veren kişi açısından incelenmiştir. BP kuşağının \%2,8'i, x kuşağının \%25,9'u ve y kuşağının \%84,2'sinde doğumların nasıl sonuçlanacağına hekim karar vermiştir. Kuşaklara göre doğumun nasıl sonuçlanacağ1 kararını veren kişilerin oranları arasında istatistiksel olarak anlamlı farklilık saptanmıştır ( $p=0,001 ; p<0,01)$ (Tablo 2). Y kuşağı kadınlarda doğumun nasıl sonuçlanacağı kararını veren kişinin doktor olma oranı yüksekken, BP kuşağı kadınların çoğu (\%80,6) 'doğumlarınızın nasıl sonuçlanacağına kim karar verdi?’ sorusuna 'çevrem' yanıtını vermiştir. Burada kastedilen aile ve sosyal çevredir. Kuşak değiştikçe yanıtlar da değişmiştir. Uysal'ın (2017) çalışmasında, kadınların \%94,3'ünün doğum şeklini seçemediği; \%69,7'sinin ise doğuma yardımcı olacak ebe ya da hekimi seçemediği belirtilmiştir. $^{22}$ Vatansever ve Okumuş'un (2013) çalışmasında, gebelerin çoğunun $(\% 81,3)$ doğum şekline karar verme sürecinde söz sahibi olmayı istedikleri belirtilmektedir. ${ }^{1}$ Çalışmamızda doğum öncesi bakım alma durumunun ve kuşaklararası eğitim farkının doğumla ilgili kararlarda söz sahibi olmaya etkisi ve kuşaklara yansıması görülmektedir.

BP kuşağı kadınlarının \%2,8'i, x kuşağının $\% 14,8$ 'i, y kuşağının ise \%55,3'ü doğum sırasında bilgilendirildiklerini belirtmişlerdir. Kuşaklara göre kadınların doğum sırasında 
doğumla ilgili bilgilendirilme oranları arasında istatistiksel olarak anlamlı farklılık saptanmıştır $(p=0.001 ; p<0.01)$; x kuşağ1 ve y kuşağı kadınların doğum sırasında doğumla ilgili bilgilendirilme oranı, BP kuşağ 1 kadınlarından daha yüksektir (Tablo 2). Doğum sirasında bilgilendirme desteği, kadının doğum sürecini anlamasını, doğum korkusunun azalmasını, endişelerinden kurtularak baş etmesinin kolaylaşmasını ve olumlu bir doğum deneyimi yaşamasını sağlayan destekleyici bakım aktivitelerinden biridir. 23, 24 Dağlar ve Güler'in (2004) çalışmalarında, ebelerin bilgi vermeye yönelik girişimleri istenilen düzeyde yapmadıkları bulunmuştur. ${ }^{23}$ Özcan ve Aslan'ın (2015) çalışmalarında da, sezaryen doğum yapan lohusalarda bilgilendirme açısından memnuniyetin normal doğum yapanlara göre daha yüksek olduğu bulunmuştur. $^{24}$

Kadınlar doğum sirasında yanında bulunanlar açısından incelendiğinde de, BP kuşağı kadınlarının \%88,9'unun yanında diplomasız ebe veya bir yakını, x kuşağının \%51,9'unun yanında ebe olduğu belirlenmiştir. Y kuşağının \%39,5'inin yanında doğum sırasında sadece ebe, \%34,2'sinin yanında ise ebe ve doktor olduğu bulunmuş olup kuşaklara göre kadınların doğum sirasında yanında bulunanların oranları arasında da istatistiksel olarak anlamlı farklılık saptanmıştır $\quad(p=0,001$; $\mathrm{p}<0.01$ ). Dolayısıyla çalışmamızda doğum esnasında kadının yanında ebe ya da doktor bulunmasına paralel olarak $\mathrm{x}$ ve y kuşağ kadınlarında doğumda bilgilendirilme oranı BP kuşağından yüksek çıkmıştır. Ancak hem $\mathrm{x}(\% 14,8)$ hem de $\mathrm{y}$ kuşağında $(\% 55,3)$ doğum sirasında kadinlara verilen bilgilendirme desteğinin düşük düzeyde olduğu görülmektedir (Tablo 2).

BP kuşağı kadınlarının \%30,6'sı, x kuşağının \%66,7'si, y kuşağının ise \%73,7'si doğum korkusu yaşamıştır. Kuşaklara göre kadınların doğum korkusu yaşama oranları arasında istatistiksel olarak anlamlı farklilık saptanmıştır ( $p=0,001 ; p<0,01)$; kuşağ1 ve y kuşağı kadınların doğum korkusu yaşama oranı, BP kuşağı kadınlarından daha yüksektir. Kadınların doğum ağrısı algıları arasında da istatistiksel olarak anlaml farklılık saptanmıştır $(\mathrm{p}=0.001 ; \mathrm{p}<0.01) ; \mathrm{BP}$ kuşağı kadınların doğum ağnısı düzeyinin hafif ve orta olma oranı yüksekken, x kuşağ1 ve y kuşağ 1 kadınlarda ise şiddetli olma oranı daha yüksektir (Tablo 2). Kadınların vajinal doğumda ağrı beklentileri sezaryen doğuma göre daha fazladır. Doğum korkusu, tıbbi bir neden olmaksızın sezaryen istemek için en yaygin nedendir. Gebelik döneminde destek alan kadınlarda doğum korkusunun azalabileceği belirtilmektedir. ${ }^{2}$,

Çalışmamızda, y kuşağında doğum öncesi kontrollere gitme oranlarının yüksek ve içinde bulundukları kuşak dolayısıyla sağlık kurumu, internet ve benzeri yerlerden yararlanma durumu olmasına rağmen hem doğum korkusu hem de ağrı algıları yüksek düzeyde bulunmuştur. Buna karşın BP kuşağının doğum ağrısı ve doğum korkusuna bakışı x ve y kuşağından farklıdır. Taghizdeh ve arkadaşlarının (2017), kadınların doğum sırasındaki ağrı deneyimlerini araştırmak amacıyla yaptıkları nitel çalışmada da, katılımcıların çoğunda kültürel ve dini faktör kaynaklı ağrıya karşı olumlu deneyim ve tutum olduğu bulunmuştur. Çalışmada doğum sırasında kadının ruhsal ve zihinsel durumunun sağlık çalışanları için ağrıyı anlamada yol gösterici olacağ1 belirtilmektedir. ${ }^{25}$

Kadınların emzirme zamanlarına bakıldığında BP kuşağı kadınlarının \%47,2'si, x kuşağının \%92,6'sı, y kuşağının ise \%89,5'i bebeklerini ilk bir saat içinde emzirmiştir. Kuşaklara göre kadınların doğum sonrası emzirme zamanları arasında istatistiksel olarak anlamlı farklılık saptanmıştır ( $\mathrm{p}=0,001$; $\mathrm{p}<0,01)$; x kuşağ 1 ve y kuşağ 1 kadınların doğum sonrası bebeği emzirme zamanlarının ilk bir saat içinde olma oranı, BP kuşağı kadınların ise saatler sonra olma oranı daha yüksektir (Tablo 2).

Kuşaklara göre kadınların doğum sonrası hemen emzirmeme nedenleri arasinda da istatistiksel olarak anlamlı farklılık saptanmıştır ( $p=0,001 ; p<0,01)$; BP kuşağ1 kadınların üç ezan bekleme geleneğinden dolayı emzirmeme oranı, y kuşağı kadınların 
ise tıbbı gerekçelerden dolayı emzirmeme oranı daha yüksektir. Çalışmamıza katılan $\mathrm{x}$ kuşağ1 kadınlarının tamamı doğumdan sonra bebeklerini hemen yanlarına almış ve ilk 1 saat içinde emzirmişlerdir. Y kuşağı kadınlarında da emzirme oranı \%92 olup doğumdan sonra bebeklerini emziremeyenlerin nedenleri ise çeşitli tıbbi gerekçelerdir. BP kuşağındaki hemen hemen tüm kadınların, gebelik, doğum ve bebek bakımı ile ilgili süreçlerde aile büyükleri ve çevre kontrolünde davranmak ve geleneklere uymak durumunda kaldıklarını ve başka seçenekleri olmadığını ifade ettikleri dikkat çekmiştir. Görüşmeler süresince bu kuşaktaki kadınların 'büyüklerimiz bebeği ne zaman verirse o zaman alıyorduk', 'adetler öyleydi' gibi söylemleri ortak özellik taşımaktaydı. BP kuşağındaki doğumdan sonra bebeğini hemen emzirmeyen kadınların tamamının gerekçesi üç ezan bekleme geleneğiydi. Bazı inanışlar ve geleneksel uygulamalar geç emzirmeye etkili olan önemli bir faktör olup bu gelenek de bunlardan biridir. $^{26}$ Akman ve Gözüyeşil'in (2018) doğum sonu dönemde geleneksel uygulamalara yönelik yapılan araştırmaları incelenmek amacıyla yaptıkları literatür derlemesinde de bebeği beslemek için üç ezan beklenmesinin Türkiye'deki emzirmeye yönelik başlıca geleneksel uygulamalardan biri olduğu bulunmuştur. ${ }^{27}$ Ayrıca Türkiye'de değişik bölgelerde yapılmış çalışmalar, sağlığa olumsuz etkisi olan bebeği emzirmek için üç ezan bekleme geleneğinin varlığını ve zaman içinde azalsa da uygulandığını belirtmektedir. Sağlık sisteminin anne sütü ve emzirmeyi desteklemesi ve bu konuda farkındalığın artması doğumdan sonra ilk bir saat içinde emzirme oranlarının artmasını ve üç ezan bekleme geleneğinin azalmasını sağlamıştır. ${ }^{28,29}$ Ayrıca yeni doğanların ilk bir saat içinde emzirilmelerinde ebe ve hemşire önerisinin etkili olduğu belirtilmektedir. ${ }^{30}$ Çalışmamızda da üç kuşak kadında sağlık kurumu ve sağlık çalışanıyla temasa bağlı olarak bebekle ilk buluşma ve emzirme yöneliminin değişmesiyle bu etkiler görülmektedir. Literatürde, emzirme ile ilgili kuşaklararası deneyimlerin uygulamadaki rolünü değerlendirmek için Fransa'da yapılmış bir çalışma yer almaktadır. Bu çalışmada, kadının annesinin ve önceki emzirme deneyiminin emzirme davranışları üzerinde önemli etkiye sahip olduğu bulunmuştur. Kendileri emzirilen annelerin bebeklerini emzirmeye başlama ve devam etmelerinin daha olası olduğu belirtilmektedir. ${ }^{31}$

Çalışmamızda BP kuşağı kadınlarının \%77,8'i, x kuşağının \%44,4'ü, y kuşağının ise $\% 21,1$ 'i doğumu kolay ve güzel bir deneyim olarak değerlendirmiş olup kuşaklara göre kadınların doğumla ilgili düşünceleri arasında istatistiksel olarak anlamlı farklılık saptanmıştır $(p=0,001 ; p<0,01)$. BP kuşağ kadınların doğumun kolay ve güzel olduğunu hissetme oranı, $\mathrm{x}$ kuşağı ve y kuşağ kadınların ise doğumun çok zor olduğunu hissetme oranı daha yüksektir (Tablo 2). Kadınların doğuma yönelik algıları ve yorumları, bireysel özellikleri, beklentileri ve yaşadıkları kültüre bağlı olarak değişiklik gösterebilmektedir. ${ }^{32}$ Pınar ve arkadaşlarının (2009) çalışmasında, annelerin \%47,3'ü doğumu çok kolay, \%31,3'ü sıkıntıl1, \%11,3'ü çok zor, \%10'u ise ameliyattan sonra güç şeklinde değerlendirmişlerdir. ${ }^{33}$ Yeşilçiçek Çalık ve Kömürcü'nün (2014) çalışmasında, annelerin doğum eylemine ilişkin düşüncelerini en çok "ağrılı ve zor ama sonu var" şeklinde ifade ettikleri bulunmuştur. ${ }^{34}$ Doğal ve ağrılı bir süreç olan doğumun kadın tarafından anlamlandırılması sosyokültürel yap1 tarafindan belirlenmektedir. ${ }^{32}$ Çalışmamızda BP kuşağı kadınlarının doğumu kolay olarak değerlendirmelerinin yaşadıkları toplumun doğum davranışlarından kaynaklandığını düşünmekteyiz. Doğumların büyük çoğunluğunun evde diplomasız ebe tarafından gerçekleştiği bu kuşak kadınlarında veri toplama sürecinde 'o zamanlar herkes öyle doğuruyordu' söylemi ve bu süreci doğal olarak değerlendirmeleri dikkat çekiciydi. Sağlık hizmetlerine ulaşılabilirliğin ve seçeneklerin artmasıyla olumlu sağlık sonuçları sağlanmasına rağmen hastane koşullarında yaşanan travmatik deneyimler ve iletişim araçlarından kaynaklanan bilgi karmaşası nedeniyle $\mathrm{x}$ ve $\mathrm{y}$ kuşağ 1 kadınlarının doğumu zor olarak değerlendirdikleri düşünülmektedir. 
Tablo 2: Kadınların Gebelik, Doğum ve Doğum Sonu Sürecine İlişkin Özellikleri ve Kuşaklararası Değerlendirilmesi

\begin{tabular}{|c|c|c|c|c|c|}
\hline & \multicolumn{3}{|c|}{ Kuşak } & \multirow[b]{3}{*}{ p } \\
\hline & & \multirow{2}{*}{$\begin{array}{c}\text { BP }(n=36) \\
n(\%)\end{array}$} & \multirow{2}{*}{$\begin{array}{c}X(n=27) \\
n(\%)\end{array}$} & \multirow{2}{*}{$\begin{array}{c}\mathrm{Y}(\mathrm{n}=38) \\
\mathrm{n}(\%)\end{array}$} & \\
\hline & & & & & \\
\hline Son Gebeliğin İsteyerek & İsteyerek Planlı & $12(33,3)$ & $16(59,3)$ & $30(78,9)$ & $\mathbf{c} 0,001 * *$ \\
\hline \multirow[t]{3}{*}{ Olma Durumu } & İsteyerek Plansız & $12(33,3)$ & $4(14,8)$ & $2(5,3)$ & \\
\hline & Eş İsteği İle & $5(13,9)$ & $1(3,7)$ & $0(0)$ & \\
\hline & İstemeyerek & $7(19,4)$ & $6(22,2)$ & $6(15,8)$ & \\
\hline Gebeliklerinde Doğum & Evet & $2(5,6)$ & $14(51,9)$ & $36(94,7)$ & b0,001** \\
\hline Öncesi Kontrole Gitme & Hayır & $34(94,4)$ & $13(48,1)$ & $2(5,3)$ & \\
\hline Doğumun Nasıl & Doktor & $1(2,8)$ & $7(25,9)$ & $32(84,2)$ & $\mathbf{c} \mathbf{0 , 0 0 1 * *}$ \\
\hline Sonuçlanacağı Kararını & Kendim ve Doktor & $0(0)$ & $2(7,4)$ & $5(13,2)$ & \\
\hline \multirow[t]{2}{*}{ Veren Kişi } & Çevre & $29(80,6)$ & $9(33,3)$ & $1(2,6)$ & \\
\hline & Kendim ve Eşim & $6(16,7)$ & $9(33,3)$ & $0(0)$ & \\
\hline Doğumu Yaptıranın & Yeterli & $22(61,1)$ & $13(48,1)$ & $23(60,5)$ & b0,678 \\
\hline \multirow[t]{2}{*}{ Desteğini Değerlendirme } & Yetersiz & $4(11,1)$ & $6(22,2)$ & $7(18,4)$ & \\
\hline & Kismen Yeterli & $10(27,8)$ & $8(29,6)$ & $8(21,1)$ & \\
\hline Doğum Sırasında Doğumla & Evet & $1(2,8)$ & $4(14,8)$ & $21(55,3)$ & ${ }^{\mathrm{b}} \mathbf{0 , 0 0 1 * *}$ \\
\hline İlgili Bilgilendirilme & Hayır & $35(97,2)$ & $23(85,2)$ & $17(44,7)$ & \\
\hline Doğum Sırasında & Ebe & $1(2,8)$ & $14(51,9)$ & $15(39,5)$ & $\mathbf{c} \mathbf{0 , 0 0 1} * *$ \\
\hline \multirow[t]{5}{*}{ Yanındakiler } & Ebe ve Doktor & $0(0)$ & $5(18,5)$ & $13(34,2)$ & \\
\hline & Doktor & $0(0)$ & $1(3,7)$ & $9(23,7)$ & \\
\hline & Ebe, Doktor ve Eşi & $0(0)$ & $0(0)$ & $1(2,6)$ & \\
\hline & Diplomasız Ebe/Yakını & $32(88,9)$ & $7(25,9)$ & $0(0)$ & \\
\hline & Yalnız Kendisi & $3(8,3)$ & $0(0)$ & $0(0)$ & \\
\hline \multirow[t]{2}{*}{ Doğum Korkusu Yaşama } & Evet & $11(30,6)$ & $18(66,7)$ & $28(73,7)$ & ${ }^{\mathbf{b}} \mathbf{0 , 0 0 1} * *$ \\
\hline & Hayır & $25(69,4)$ & $9(33,3)$ & $10(26,3)$ & \\
\hline \multirow[t]{4}{*}{ Doğum Ağrısı Düzeyi } & Hafif & $13(36,1)$ & $2(7,4)$ & $4(10,5)$ & b0,001** \\
\hline & Orta & $13(36,1)$ & $7(25,9)$ & $7(18,4)$ & \\
\hline & Şiddetli & $8(22,2)$ & $15(55,6)$ & $15(39,5)$ & \\
\hline & Çok Şiddetli & $2(5,6)$ & $3(11,1)$ & $12(31,6)$ & \\
\hline Doğum Sonrası Emzirme & İlk Bir Saat İçinde & $17(47,2)$ & $27(100)$ & $35(92,1)$ & $\mathbf{c} 0,001 * *$ \\
\hline \multirow[t]{2}{*}{ Zamanı } & Saatler Sonra & $19(52,8)$ & $0(0)$ & $1(2,6)$ & \\
\hline & Günler Sonra & $0(0)$ & $0(0)$ & $2(5,3)$ & \\
\hline Doğum Sonrası Hemen & Tıbbi Gerekçe & $0(0)$ & $0(0)$ & $3(100)$ & $\mathbf{c}_{0,001 * *}$ \\
\hline Emzirmeme Nedeni(N=22) & Üç Ezan Bekleme Geleneği & $19(100)$ & $0(0)$ & $0(0)$ & \\
\hline \multirow[t]{7}{*}{ Doğumla İlgili Düşünceleri } & Fena değildi & $2(5,6)$ & $2(7,4)$ & $7(18,4)$ & $\mathbf{c} 0,001 * *$ \\
\hline & Kolay ve güzeldi & $28(77,8)$ & $12(44,4)$ & $8(21,1)$ & \\
\hline & Mucize & $0(0)$ & $0(0)$ & $4(10,5)$ & \\
\hline & $\begin{array}{l}\text { Zor fakat güzel bir deneyim } \\
\text { Acı verici }\end{array}$ & $4(11,1)$ & $5(18,5)$ & $10(26,3)$ & \\
\hline & Çok zor & $1(2,8)$ & $3(11,1)$ & $1(2,6)$ & \\
\hline & Korkunç & $1(2,8)$ & $5(18,5)$ & $7(18,4)$ & \\
\hline & & $0(0)$ & $0(0)$ & $1(2,6)$ & \\
\hline
\end{tabular}

Kadınların yaşadıkları ve tercih ettikleri doğum şekli özellikleri ve kuşaklararası değerlendirilmeleri Tablo 3'de verilmiştir. Kuşaklara göre doğum şekilleri arasında her üç doğum için de istatistiksel olarak anlamlı farklılık saptanmıştır $(p<0,01)$. 
Tablo 3: Kuşakların Doğum Şekli Açısından Değerlendirilmesi

\begin{tabular}{|c|c|c|c|c|c|}
\hline \multirow[b]{3}{*}{ Doğum sayısı } & \multirow[b]{3}{*}{ Doğum şekli } & \multicolumn{3}{|c|}{ KUŞAK } & \multirow[b]{3}{*}{$\mathbf{p}$} \\
\hline & & BP Kuşağı & X Kuşağı & Y Kuşağı & \\
\hline & & n (\%) & n (\%) & n (\%) & \\
\hline \multirow[t]{2}{*}{ 1.doğum $(n=101)$} & Vajinal & $36(100)$ & $26(96,3)$ & $29(76,3)$ & ${ }^{\mathrm{b}} 0,001 * *$ \\
\hline & Sezaryen & $0(0)$ & $1(3,7)$ & $9(23,7)$ & \\
\hline \multirow[t]{2}{*}{ 2.doğum $(n=93)$} & Vajinal & $36(100)$ & $24(92,3)$ & $21(67,7)$ & ${ }^{\mathrm{b}} \mathbf{0 , 0 0 0} * *$ \\
\hline & Sezaryen & $0(0)$ & $2(7,7)$ & $10(32,3)$ & \\
\hline \multirow[t]{2}{*}{ 3.doğum $(n=72)$} & Vajinal & $33(100)$ & $19(90,5)$ & $7(38,9)$ & ${ }^{b} 0,000 * *$ \\
\hline & Sezaryen & $0(0)$ & $2(9,5)$ & $11(61,1)$ & \\
\hline \multirow{3}{*}{$\begin{array}{l}\text { Yeniden Doğurmak } \\
\text { İstediğinde Tercih } \\
\text { Edilen Doğum Şekli }\end{array}$} & Normal Doğum & $35(97,2)$ & $23(85,2)$ & $26(68,4)$ & ${ }^{\mathrm{b}} 0,004 * *$ \\
\hline & Sezaryen & $1(2,8)$ & $4(14,8)$ & $12(31,6)$ & \\
\hline & & & & & \\
\hline \multirow{4}{*}{$\begin{array}{l}\text { Doğumu } \\
\text { Yaptırmasını } \\
\text { İstediği Kişi }\end{array}$} & Doktor & $8(22,2)$ & $11(40,7)$ & $25(65,8)$ & $\mathbf{c} 0,002 * *$ \\
\hline & & & & & \\
\hline & Ebe & $22(61,1)$ & $14(51,9)$ & $10(26,3)$ & \\
\hline & $\begin{array}{l}\text { Kadın Olması Önemli } \\
\text { (Doktor Ya Da Ebe) }\end{array}$ & $6(16,7)$ & $2(7,4)$ & $3(7,9)$ & \\
\hline \multirow{6}{*}{$\begin{array}{l}\text { Doğum Sırasında } \\
\text { Yanında Olmasını } \\
\text { İstediği Kişiler }\end{array}$} & Anne & $0(0)$ & $1(3,7)$ & $5(13,2)$ & $\mathbf{c}_{0,001 * *}$ \\
\hline & Eş & $0(0)$ & $0(0)$ & $11(28,9)$ & \\
\hline & Kardeş & $0(0)$ & $1(3,7)$ & $2(5,3)$ & \\
\hline & Yakınlarından Biri & $6(16,7)$ & $5(18,5)$ & $3(7,9)$ & \\
\hline & Sağlıkçı Dişında & $30(83,3)$ & $20(74,1)$ & $17(44,7)$ & \\
\hline & Kimse Olmasin & & & & \\
\hline
\end{tabular}

Sezaryen oranları y kuşağında daha yüksektir. Birinci doğumlar BP kuşağı kadınlarda \%100, x kuşağında \%96,3, y kuşağında ise \%76,3 vajinal doğumdur. Y kuşağında vajinal doğum oranının ikinci doğumda \%67,7'ye, üçüncü doğumda ise \%38,9'a düştüğü bulunmuştur. Tibbi zorunluluklar dışında kadınların doğum korkusu, doğum ile ilgili negatif duyumlar, bilgi yetersizliği ve sağlık çalışanının malpraktis çekincesi gibi nedenlerle sezaryene eğilim artmaktadır. ${ }^{2}$ Türkiye'deki sezaryen oranlarının artışına paralel olarak çalışmamıza katılan kadınlar arasında da zaman içinde normal vajinal doğum sayılarının azaldığı ve sezaryen oranının y kuşağ1 kadınlarında oldukça yüksek olduğu görülmektedir.

Kadınlar yeniden doğurmak istediklerinde tercihleri edecekleri doğum şekilleri açısından incelendiğinde BP kuşağı kadınların \%97,2'si, x kuşağının \%85,2'si, y kuşağının ise \%68,4'ünün normal doğumu tercih edeceği bulunmuştur. Kuşaklara göre tercih edilen doğum şekilleri arasında istatistiksel olarak anlamlı farklılık saptanmıştır $(\mathrm{p}=0.004$; $\mathrm{p}<0.01)$; x kuşağı ve y kuşağı kadınların yeniden doğurmak istediğinde sezaryen doğumu tercih etme oranı, BP kuşağ kadınların ise normal doğum tercih etme oranı daha yüksektir. Kadınlara tercih nedenleri açık uçlu olarak sorulmuştur. Normal doğum tercih edenler sırası ile 'bel ağrisı olmaz, yarım olmazsın, sezaryen sonrası ağır kaldıramazsın, narkoz almazsın, hemen kalkıp işlerini yapabilirsin, ameliyatın sorunları ömür boyu sürer, normal doğumun acısı kısa sürer ve doğum sonu ağrı olmaz' şeklinde açıklama yapmışlardır. Sezaryen doğum ise ağrı ve acı olmaması, doğum korkusu, epizyo ve fundal bası korkusu, tüpligasyon isteği ve önceki doğumun sezaryen olması nedeni ile tercih edilmiştir. Doğum şekli tercihi doğum korkusu, sosyoekonomik faktörler, bireysel istek, hekim isteği ve çevre gibi birçok faktörden etkilenmektedir. Doğum korkusunun farklı nedenleri olmakla beraber temelinde ağrı yatmaktadır. Kadınlar sezaryen doğumu doğum ağrısını önlemenin bir yolu olarak görebilmektedir. Literatürde benzer sonuçları gösteren birçok çalışma mevcut 
olup doğum şekli tercihi ve nedenleri yönünden çalışmamızın bulguları literatürle uyum göstermektedir., ${ }^{2,16,35}$ Çalışmamızda kadınların doğumlarını yaptırmasını istediği kişi açısından kuşaklar arasında istatistiksel olarak anlamlı farklılık saptanmıştır $(\mathrm{p}=0.002$; $\mathrm{p}<0.01)$. BP kuşağ1 ve $\mathrm{x}$ kuşağı kadınların doğumu ebenin yapmasını isteme oranı (sıras1 ile: \%61,1 ve \%51,9), y kuşağı kadınların ise doğumu doktorun yapmasinı isteme oranı $(\% 65,8)$ daha yüksektir (Tablo 3). Tarih boyunca tüm toplumlarda ebeler çeşitli doğal tekniklerle doğuma yardımcı olmuşlardır. Günümüzde ebeliğin bilimsel gelişmeler doğrultusunda gelişen bir meslek olmasına rağmen ülkemizde ev doğumlarından uzaklaşılması ve doktor ya da kadının tercihine bağlı elektif hale gelen sezaryenin artmasıyla ebelik mesleği gerilemeye başlamıştır. ${ }^{36}$ Başgöl ve Kızılkaya Beji'nin (2015) derleme çalıșmasında, kadınların ebe yönetiminde aldıkları bakımdan daha memnun oldukları, doğumda bölgesel anestezi, epizyotomi ve müdahaleli doğumların daha az, kendiliğinden vajinal doğumların daha fazla olduğu, ayrıca ebe yönetimindeki doğumlarda 24 haftadan önceki bebek ölümlerinin ve erken doğumların daha az olduğu bildirilmektedir. ${ }^{37}$ BP ve x kuşağı kadınlarının, ev doğumlarının gündemde olduğu, ebelerin ev ziyareti yaptığı, ebelik hizmetlerinin daha etkin yürütüldüğü dönemlere tanıklık etmiş olmaları doğumu ebelerin yaptırması gerekliliğini düşünmelerine neden olmuş olabilir. Y kuşağı kadınlarının çoğunun $(\% 84,2)$ doğumunun nasıl sonuçlanacağına doktor karar vermiş ve doğum öncesi kontrolleri daha çok doktor tarafindan yapılmıştır. Bu doğrultuda y kuşağı kadınları doğumlarının doktor tarafindan geçekleştirilmesini istiyor olabilir.

Kuşaklara göre kadınların doğum sırasında yanında olmasını istediği kişiler arasında da istatistiksel olarak anlaml farklılık saptanmıştır $(p=0.001 ; p<0.01)$. BP kuşağ ve $\mathrm{x}$ kuşağı kadınların doğum sırasında yanında sağlıkçı dışında kimsenin olmasını istememe oranı (sırası ile: \%83,3 ve \%74,1), y kuşağ kadınların ise doğum sırasında yanında eşlerinin olmasını isteme oranı $(\% 28,9)$ daha yüksektir (Tablo 3). Hem gebelik hem de doğum sürecinde sosyal destek çok önemli olup birçok kültürde kadınlar yakınları, arkadaşları ve ebeler tarafindan desteklenmekte, bu desteğin de kadının emosyonel sağlığına ve doğum çıktılarına olumlu etkileri olmaktadır. Timur ve Hotun Şahin'in (2010) kadınların doğum eylemi sırasındaki sosyal destek deneyim ve tercihlerini inceledikleri çalışmalarında, kadınların çoğunun $(\% 74,5)$ doğumda destekleyici birine ihtiyaç duyduğu, desteği istenen kişilerin ise sirasıyla annesi, eşi, kardeşi ve bir sağlik personeli şeklinde olduğu bulunmuştur. ${ }^{6}$ Güleç ve arkadaşlarının (2014) çalışmalarında da, gebelik döneminde sosyal destek düzeyleri arttıkça kadınların doğum korkularının azaldığ 1 belirtilmektedir. ${ }^{38}$ Çalışmamızda kadınların eğitim düzeyindeki farklılıkların, değişen kültürel ve toplumsal değerlerin, y kuşağı kadınlarında doğum sırasında eş desteğine olumlu bakmalarına yansımasının olduğu görülmektedir

Kadınların ilk üç doğumlarının yapıldığ yer, doğumu yaptıran kişi ve epizyotomi yönünden özellikleri ve bunların kuşaklararası karşılaştırılmaları Tablo 4'de verilmiştir. Kuşaklara göre kadınların doğumlarını yaptıkları yerlerin oranları arasında istatistiksel olarak anlaml farklilik saptanmıştır. BP kuşağı kadınların \%5,6'sı, x kuşağının \%55,6's1 ve y kuşağının \%100'ü ilk doğumlarını hastanede gerçekleştirmiştir. Her üç doğum için de; BP kuşağı kadınların evde doğum yapma oranları, x kuşağı ve y kuşağı kadınlardan daha yüksektir. $X$ kuşağ kadınların evde doğum yapma oranları da y kuşağı kadınlardan daha yüksektir $(\mathrm{p}=0,001$; $\mathrm{p}<0,01$ ) (Tablo 4). Sağlıklı gebeliğe sahip kadınların herhangi bir müdahale olmaksızın evde doğum yapabileceği belirtilse de öngörülemeyen komplikasyonlar nedeniyle ülkemiz de dâhil birçok ülkede doğumların hastanede olması önerilmektedir. ${ }^{37}$ 
Tablo 4. Kuşaklara Göre İlk Üç Doğuma İlişkin Değerlendirmeler

\begin{tabular}{|c|c|c|c|c|c|c|}
\hline \multirow{3}{*}{$\begin{array}{l}\text { Doğum } \\
\text { sıralaması }\end{array}$} & \multirow[b]{3}{*}{ Doğum yeri } & \multirow[b]{2}{*}{ Toplam } & \multicolumn{3}{|c|}{ Kuşak } & \multirow[b]{3}{*}{$\mathbf{p}$} \\
\hline & & & BP Kuşağı & X Kuşağ & Y Kuşağı & \\
\hline & & n (\%) & n (\%) & n (\%) & n (\%) & \\
\hline \multirow{2}{*}{$\begin{array}{l}\text { 1.doğum } \\
(n=101)\end{array}$} & Hastane & $55(54,5)$ & $2(5,6)$ & $15(55,6)$ & $38(100)$ & \multirow[t]{2}{*}{ b0,001** } \\
\hline & Ev & $46(45,5)$ & $34(94,4)$ & $12(44,4)$ & $0(0)$ & \\
\hline \multirow{3}{*}{$\begin{array}{l}\text { 2.doğum } \\
(\mathbf{n}=93)\end{array}$} & Hastane & $44(47,3)$ & $0(0)$ & $14(53,8)$ & $30(96,8)$ & \multirow[t]{3}{*}{ c0,001** } \\
\hline & Ev & $48(51,6)$ & $36(100)$ & $11(42,3)$ & $1(3,2)$ & \\
\hline & Sağlık ocağı & $1(1,1)$ & $0(0)$ & $1(3,8)$ & $0(0)$ & \\
\hline \multirow{2}{*}{$\begin{array}{l}\text { 3.doğum } \\
(n=72)\end{array}$} & Hastane & $33(45,8)$ & $3(9,1)$ & $13(61,9)$ & $17(94,4)$ & \multirow[t]{2}{*}{${ }^{\mathbf{b}} \mathbf{0 , 0 0 1} * *$} \\
\hline & Ev & $39(54,2)$ & $30(90,9)$ & $8(38,1)$ & $1(5,6)$ & \\
\hline
\end{tabular}

Doğumu yapttran kişi

\begin{tabular}{|c|c|c|c|c|c|c|}
\hline 1.doğum & Ebe & $39(38,6)$ & $3(8,3)$ & $15(55,6)$ & $21(55,3)$ & $\mathbf{c} \mathbf{0 , 0 0 1} * *$ \\
\hline \multirow[t]{3}{*}{$(n=101)$} & Doktor & $20(19,8)$ & $0(0)$ & $3(11,1)$ & $17(44,7)$ & \\
\hline & Diplomasız ebe & $39(38,6)$ & $30(83,3)$ & $9(33,3)$ & $0(0)$ & \\
\hline & Kendisi & $3(3)$ & $3(8,3)$ & $0(0)$ & $0(0)$ & \\
\hline \multirow{4}{*}{$\begin{array}{l}\text { 2.doğum } \\
(\mathrm{n}=93)\end{array}$} & Ebe & $28(30,1)$ & $1(2,8)$ & $13(50)$ & $14(45,2)$ & $\mathrm{c} 0,001 * *$ \\
\hline & Doktor & $18(19,4)$ & $0(0)$ & $2(7,7)$ & $16(51,6)$ & \\
\hline & Diplomasız ebe & $43(46,2)$ & $31(86,1)$ & $11(42,3)$ & $1(3,2)$ & \\
\hline & Kendisi & $4(4,3)$ & $4(11,1)$ & $0(0)$ & $0(0)$ & \\
\hline \multirow{4}{*}{$\begin{array}{l}\text { 3.doğum } \\
(n=72)\end{array}$} & Ebe & $20(27,8)$ & $3(9,1)$ & $12(57,1)$ & $5(27,8)$ & $\mathbf{c} 0,001 * *$ \\
\hline & Doktor & $15(20,8)$ & $0(0)$ & $2(9,5)$ & $13(72,2)$ & \\
\hline & Diplomasız ebe & $31(43,1)$ & $25(75,8)$ & $6(28,6)$ & $0(0)$ & \\
\hline & Kendisi & $6(8,3)$ & $5(15,2)$ & $1(4,8)$ & $0(0)$ & \\
\hline
\end{tabular}

\section{Epizyotomi}

\begin{tabular}{|c|c|c|c|c|c|c|}
\hline 1.doğum & Evet & $41(40,6)$ & $1(2,8)$ & $11(40,7)$ & $29(76,3)$ & ${ }^{\mathrm{b}} \mathbf{0 , 0 0 1 * * *}$ \\
\hline$(\mathbf{n}=101)$ & Hayır & $60(59,4)$ & $35(97,2)$ & $16(59,3)$ & $9(23,7)$ & \\
\hline 2.doğum & Evet & $20(21,5)$ & $0(0)$ & $4(15,4)$ & $16(51,6)$ & $\mathrm{b}_{0,001}$ *** \\
\hline$(\mathrm{n}=93)$ & Hayır & $73(78,5)$ & $36(100)$ & $22(84,6)$ & $15(48,4)$ & \\
\hline 3.doğum & Evet & $10(13,9)$ & $0(0)$ & $5(23,8)$ & $5(27,8)$ & ${ }^{c} 0,002 * *$ \\
\hline$(n=72)$ & Hayır & $62(86,1)$ & 33 (100) & $16(76,2)$ & $13(72,2)$ & \\
\hline
\end{tabular}

Türkiye'de evde gerçekleşen doğumların gösterildiği değişik yıllarda yapılmış çalışmalar mevcuttur. ${ }^{30,} 39$ Evde doğum sosyal, kültürel, eğitim ve ekonomik düzey ile ilişkilidir. ${ }^{39}$ TNSA sonuçlarına göre sağlık kuruluşlarında gerçekleşen doğumların, 1993'de \%60 iken 2003'de \%78, 2008'de $\% 90,2013$ 'de \%97, 2018'de ise \%99 olduğu; evde doğumların ise \%1'in altına düştüğü görülmektedir. ${ }^{3}$ Çalışmamızda, BP kuşağ 1 kadınlarında evde doğum oranları her üç doğum için de çok yüksektir (Sırası ile: \%94,4; \%100; \%90,9). Y kuşağında iki tane evde doğum bulunmuş olup bu doğumlar aynı kadına ait ikinci ve üçüncü doğumlarıdır. İkinci doğumu evde diplomasız ebe olan kayınvalidesi, üçüncü doğumu ise son anda haber verilmek suretiyle evde diplomalı ebe tarafından gerçekleştirilmiştir. $\mathrm{Bu}$ doğum, çalışmanın yapıldığı bölgede son evde doğum vakası olup 2005 yılında gerçekleşmiştir.

Kuşaklara göre kadınların doğumlarını yaptıran kişilerin oranları arasında da istatistiksel olarak anlamlı farklılık saptanmıştır $(p=0,001 ; p<0,01)$. İlk doğumlar incelendiğinde ebe tarafından yaptırılan doğumlar BP kuşağında \%8,3, x kuşağında $\% 55,6$, y kuşağında ise $\% 55,3$ olarak bulunmuştur. BP kuşağında üç doğumda da doktor tarafindan yaptırılan doğum bulunmamaktadır. Doktor tarafindan yaptırılan doğumların en fazla y kuşağında 
olduğu ve zamanla arttığı görülmektedir. Y kuşağı kadınlarında ilk doğumların \%44,7'si; ikinci doğumların \%51,6'sı; üçüncü doğumların ise \%72,2'si doktor tarafından yaptırılmıştır (Tablo 4). TNSA verilerinde doğum sırasında yardım eden kişilere bakıldığında, doğumların sağlı eğitimi almış kişiler tarafından gerçekleştirilme yüzdeleri; 1993 'de $\% 76,1998$ 'de $\% 73,2003$ 'de $\% 83$ ve 2008 'de \%91, 2013'de \%97 ve 2018 verilerinde ise doğumların neredeyse tamamının (\%99) sağlık eğitimi almış kişiler tarafından gerçekleştirildiği şeklindedir. Doğumların \%83'ü doktor, \%16's1 ise ebe ve hemşire yardımıyla gerçekleşmiştir. Ebe ve hemşire yardımıyla doğum Türkiye'de bölgeler arası farklılık göstermekte, batıda $\% 7$ ile en düşük iken doğuda \%32 ile en yüksek düzeydedir. ${ }^{3}$ Bulguların ait olduğu yıllar BP kuşağı kadınlarının üreme çağını çok fazla içermemekte ancak $\mathrm{x}$ kuşağının büyük çoğunluğu ve y kuşağını içine almaktadır. Çalışmamızda da doğumun yapıldığı yerle de ilişkili olarak sağlık personeli yardımıyla gerçekleşen doğumların zamanla arttığ1 görülmektedir.

Kadınlar epizyotomi olma açısından incelendiğinde BP kuşağının \%2,8'i, x kuşağının \%40,7'si, y kuşağının ise \%76,3'ünün ilk doğumlarında epizyotomi uygulandığ 1 bulunmuştur. Kuşaklara göre kadınların her üç doğum için de epizyotomi yapılma oranları arasında istatistiksel olarak anlamlı farklılık saptanmıştır $(\mathrm{p}<0,01)$. $X$ ve y kuşağı kadınların doğumlarında epizyotomi yapılma oranı BP kuşağı kadınlarından daha yüksektir. Y kuşağı kadınlarının epizyotomi yapılma oranı da $\mathrm{x}$ kuşağı kadınlarından daha yüksektir (Tablo 4).

Perineal travmaları önlemek amacıyla rutin uygulanabilen epizyotominin komplikasyonlu olabileceği, bu nedenle gerekli klinik durumlarda sinırlı uygulamaya gidilmesi gerektiği belirtilmektedir. Dünya Sağlık Örgütü, aktif doğum yönetiminde rutin epizyotomi uygulamasını önermemektedir. ${ }^{40}$
Çalışmamızda, sağlık

kuruluşlarında gerçekleşen doğum oranlarının artışına paralel olarak epizyotomi oranlarının da arttığ1 görülmektedir.

Çalışmamızda kadınlara doğum anında ebelerin nasıl davranmasinı istedikleri sorulduğunda alınan yanıtlar Tablo 5'de verilmiştir. Ebelerin iyi davranmaları $(\% 49,5)$, azarlamamaları $(\% 28,7)$, bilgi vermeleri $(\% 17,8)$ ve ilgi göstermeleri $(\% 14,9)$ kadınların çoğunluğu tarafından beklenen davranışlardır. Değişik yıllarda yapılmış çalışmalar da ebeden beklenen davranışların her kuşak için benzer olduğunu göstermektedir. Erenel ve Akkuzu'nun (1999) kadınların doğum deneyimlerini inceledikleri çalışmalarında (n=183), kadınların \%34'ü ebelerin, \%8,6's1 da doktorların travayda kendilerine saygısız davrandığını ifade ettikleri, bu davranışların da en çok azarlama, bağırma ve hakaret etme şeklinde olduğu bulunmuştur. ${ }^{4}$ Çankaya ve arkadaşlarının (2014) çalışmasında, gebelerin ebelerden özellikle saygılı davranma, güler yüzlülük ve ilgi açısından beklentileri olduğu belirtilmektedir. ${ }^{5}$ Kadınlarda olumlu doğum deneyimi yaşanması açısından ebe yaklaşımının önemli olduğu unutulmamalıdır.

Tablo 5: Kadınların Doğum Anında Ebelerden Bekledikleri Davranışlar

\begin{tabular}{lcc}
\hline Ebelerden beklenenler & n & \% \\
\hline İyi davranmaları & 50 & 49,5 \\
Azarlamamaları & 29 & 28,7 \\
Bilgi vermeleri & 18 & 17,8 \\
İlgi göstermeleri & 15 & 14,9 \\
Yardımcı olmaları & 12 & 11,9 \\
Güler yüzlü olmaları & 10 & 9,9 \\
Anlayış göstermeleri & 8 & 7,9 \\
Güzel konuşmaları & 7 & 6,9 \\
Destek olmaları & 6 & 5,9 \\
Yumuşak olmaları & 5 & 5,0 \\
Moral vermeleri & 4 & 4,0 \\
İhtiyaçla ilgilenmeleri & 2 & 2,0 \\
Empati göstermeleri & 2 & 2,0 \\
Cesaret vermeleri & 1 & 1,0 \\
Karına bastırmamaları & 1 & 1,0 \\
\hline • Birden çok seçenek işaretlenmiştir. & &
\end{tabular}

\section{SONUÇ VE ÖNERILER}

BP, $x$ ve y kuşağı kadınlarının incelendiği çalışmamızda gebelik ve doğum özellikleri açısından kuşaklararası birçok farklılık saptanmıştır. Zaman içinde kadınlarda eğitim durumunun yükseldiği, toplam gebelik sayısında düşüş olduğu, bebek ölümlerinin, 
kendiliğinden düşük ve kürtaj sayılarının azaldığ1 görülmektedir. Bebeği emzirmeye erken başlama, planlı gebelikler ve doğum öncesi kontroller artmıştır. Kadınların doğumlarıla ilgili kararlarda söz sahibi olması olumlu yönde ilerlemiş ve sağlık çalışanı ile işbirliği devreye girmiştir. Dolayısıyla sağlık çalışanı yardımı ile doğum ve sağlik kuruluşunda gerçekleşen doğumlarda artış gerçekleşmiştir. Eğitim durumunun yükselmesi ve iyileşen sağlik sisteminin yansimasi olan bu olumlu gelişmelerin yanında kadınların doğum korkusu ve doğum ağrısı algıları açısından olumsuz sonuçların varlığı da görülmüştür. Normal vajinal doğum oranları azalmış, sezaryen tercihine eğilim artmıştır. Doğum ağrıs1 ve sezaryene bağlı gelişen rahatsızlıkların kadınlar için sorun teşkil ettiği görülmektedir. Ayrıca doğumda ebe tercihinin azalması, ebelerin gebelik ve doğum sürecinde daha etkin olmaları gerekliliğini göstermektedir.

Kadınların doğumla ilgili görüşlerinin anlaşılması hizmet etkinliği açısından önem taşımaktadır. Açıklığa kavuşturulan doğum algıları ve doğum şekline bakış açıları hem doğum öncesi bakım aşamasında özellikle değinilecek konularda hem de sağlik hizmeti planlamasında yol gösterici olabilir. Çalışmamızda üç kuşak kadınlarının gebelik ve doğum süreci ile ilgili farklı tecrübelerinin olduğu, her kadının deneyimlerini anlatmaya açık olduğu dikkat çekmekteydi. Bu bağlamda kadınların gebelik, doğum ve üreme sağlığ1 açısından daha özgül şekilde incelenmeleri faydalı olabilir. Ayrıca değişik kuşaklara mensup kadınların kendi hikâyelerini öğrenmek ve bunun kadınlar arasındaki etkileşimini anlamak için nitel çalışmaların da yapılmasının yararlı olacağı düşünülmektedir.

\section{KAYNAKLAR}

1. Vatansever, Z, Okumus, H. (2013). Gebelerin Doğum Şekline Karar Verme Durumlarının İncelenmesi. DEUHYO ED, 6 (2), 82-87.

2. Bülbül, T, Özen, B, Çopur, A, Kayacık, F. (2016). Gebelerin Doğum Korkusu ve Doğum Sekline Karar Verme Durumlarının İncelenmesi. Sağlık Bilimleri Dergisi, 25 (3), 126-130.

3. Hacettepe Üniversitesi Nüfus Etütleri Enstitüsü (2019). 2018 Türkiye Nüfus ve Sağlık Araştırması. Hacettepe Üniversitesi Nüfus Etütleri Enstitüsü, T.C. Cumhurbaşkanlığı Strateji ve Bütçe Başkanlığı ve TÜBİTAK, Ankara, Türkiye. http://www.hips.hacettepe.edu.tr/tnsa2018/ rapor/TNSA_2018_ana_Rapor.pdf Erişim Tarihi: 19.12.2019.

4. Erenel, AȘ, Akkuzu, G. (1999). Sağl1k Personeli-Hasta İlișkisine Kadın Açısından Bakış: Doğum Deneyimi. Türkiye Klinikleri Tıp Etiği Dergisi, 7 (1), 22-29.

5. Cankaya, S, Ak, A, Polat, Y, Filiz, F, Künduro, F, Mizrak, F, Yurday, H, Gülbahar, B, Han, E. (2014). Doğum için başvuran gebelerin empatik iletişim beklentilerinin ebeler tarafından karșılanma durumu. Genel Tıp Dergisi, 24, 7-14.

6. Timur, S, Hotun-Şahin, N. (2010). Kadınların Doğumda Sosyal Destek Tercihleri ve Deneyimleri. Hemșirelikte Araștırma Geliștirme Dergisi, 1, 29-40.

7. Aydın, N, Yıldız, H. (2018). Travmatik doğum deneyiminin etkileri ve nesiller arası aktarımı. Journal of Human Sciences, 15 (1), 604-618

8. Yolbulan Okan, E, Yalman, N. (2013). Türkiye'de Tartışmal Reklamlar: Kușaklar Arası Karşılaștırma. H.Ü. İktisadi ve İdari Bilimler Fakültesi Dergisi, 31 (2), 135-152.

9. Kuyucu, M. (2014). Y Kuşağı ve Facebook: Y Kuşağının Facebook Kullanım Alıskanlıkları Üzerine Bir İnceleme. Elektronik Sosyal Bilimler Dergisi, 13 (49), 55-83.

10. Kay, L, Downe, S, Thomson, G, Finlayson, K. (2017). 'Engaging with birth stories in pregnancy: a hermeneutic phenomenological study of women's experiences across two generation'. BMC Pregnancy and Childbirth, 17, 283.
11. Sharp, GC, Saunders, PT, Greene, SA, Morris, AD, Norman, JE. (2014). Intergenerational transmission of postpartum hemorrhage risk: analysis of 2 Scottish birth cohorts. American Journal of Obstetrics and Gynecology, 211 (1), 51.e1-7.

12. Smid MC, Lee, JH, Grant, JH, Miles, G, Stoddard GJ, Chapman, DA, Manuck, TA. (2017). Maternal race and intergenerational preterm birth recurrence. Am J Obstet Gynecol, 217 (4), 480.e1480.e9.

13. Nugraha, GI, Herman, H, Alisjahbana, A. (2017). Intergenerational effects of maternal birth weight, BMI, and body composition during pregnancy on infant birth weight: Tanjungsari Cohort Study, Indonesia, Asia Pac J Clin Nutr, 26 (Suppl 1), 19-25.

14. Liu, N, Vigod, SN, Farrugia, MM, Urquia, ML, Ray, JG. (2018) Intergenerational teen pregnancy: a population-based cohort study. BJOG, 125 (13), 1766-1774.

15. Aslan, Ş, Okumuş, F. (2017). Primipar Kadınların Doğum Deneyim Algıları Üzerine Doğum Beklentilerinin Etkisi. HSP, 4 (1), 32-40.

16. Çapık, A, Sakar, T, Yıldırım, N, Karabacak, K, Korkut, M. (2016). Annelerin Doğum Şekline Göre Doğumdan Memnuniyet Durumlarının Belirlenmesi. Anadolu Hemșirelik ve Sağlık Bilimleri Dergisi, 19 (2), 92-99.

17. Küçüker, E. (2017). Türkiye'de Kademeler Arası Geçiș ve Öğrenci Akışının Gelişimi. Ankara Üniversitesi Eğitim Bilimleri Fakültesi Dergisi, 50 (1), 43-97.

18. Liu, N, Farrugia, MM, Vigod, SN, Urquia, ML, Ray, JG. (2018). Intergenerational abortion tendency between mothers and teenage daughters: a population-based cohort study. CMAJ, Jan 29;190 (4), E95-E102.

19. Korkmaz A, Aydın, Ş, Duyan Çamurdan, A, Okumuş, N, Onat, FN, Özbaș, S, Polat, E, Senel, S, Tezel, B, Tezer, H, Köse, MR. (2013). Türkiye'de bebek ölüm nedenlerinin ve ulusal kayıt sisteminin değerlendirilmesi. Çocuk Sağlığı ve Hastalıkları Dergisi, 56, 105-121. 
20. Tekiner, S, Cetin F, Ceyhun, AG, Kafkaslı A. (2010) Planlanmamış Gebelikler ile Kontraseptif Yöntemler Arasındaki İlişki. Dirim Tıp Gazetesi, 85 (2), 65-71.

21. Kara, M, Kıyak Çağlayan, E, Karaçavuş, S, Erdoğan, Y. (2012). Yozgat ilinde yaşayan gebelerin sosyoekonomik ve demografik faktörler açısından değerlendirilmesi. Cumhuriyet Tıp Dergisi, 34, 158-163.

22. Uysal, B. (2017). Kadınların Doğum Deneyimi ve Doğum Sonrası Memnuniyetlerinin Değerlendirilmesi. Eskișehir Osmangazi Üniversitesi, Sağlık Bilimleri Enstitüsü, Yüksek Lisans Tezi, Eskișehir.

23. Dağlar, G, Güler, H. (2004). Ebelerin doğum anında annelere verdiği bakım hizmeti: Annelerin değerlendirmeleri ve beklentileri. https:/acikerisim. cumhuriyet. edu.tr/xmlui/handle/20.500.12418/1550 Erişim Tarihi: 21.12.1019.

24. Özcan, Ş, Aslan, E. (2015). Normal Doğumda ve Sezaryen Doğumda Anne Memnuniyetinin Belirlenmesi. Florance Nightingale Hemşirelik Dergisi, 23 (1), 41-48.

25. Taghizdeh, Z, Ebadi, A, Dehghani, M, Gharacheh, M, Yadollahi, P. (2017). A time for psycho-spiritual transcendence: The experiences of Iranian women of pain during childbirth. Women Birth. Dec; 30 (6), 491-496.

26. Bozkuş Eğri, G, Konak, A. (2011). Doğum Sonu Dönem İle ilgili Geleneksel İnanç ve Uygulamalara Dünyadan ve Türkiye'den Örnekler. Zeitschrift für die Welt der Türken, 3(1), 143-155.

27. Akman, G, Gözüyeşil, E. (2018). Doğum Sonu Dönemde Geleneksel Uygulamalara Yönelik Yapılan Araştırmaların İncelenmesi. Uluslararası Hakemli Kadın Hastalıkları ve Anne Çocuk Sağlığı Dergisi, 12 https://pdfs.semanticscholar.org/4b80/f Erişim Tarihi: 17.12.2019.

28. Arabac1, Z, Yildırım, JG, Dündar, BN, Kadam, Z. (2016). Bebeklerde Uygulanan Geleneksel Yöntemler. Çocuk ve Medeniyet, 1 (1), 61-86.

29. Arısoy, A, Canbulat, N, Ayhan, F. (2014). Karaman İlindeki Annelerin Bebeklerinin Bakımında Uyguladıkları Geleneksel Yöntemler. Anadolu Hemşirelik ve Sağlık Bilimleri Dergisi, 17 (1), 23-31.
30. Calıșkan Z, Bayat, M. (2011). Annelerin Bebek Bakımı Uygulamaları ve Etkileyen Faktörler: Bir Kapadokya Örneği. Anadolu Hemşirelik ve Sağlık Bilimleri Dergisi, 14 (2), 23-30.

31. Wagner, S, Kersuzan, C, Gojard, S, Tichit, C, Nicklaus, S, Thierry, X, Charles, MA, Lioret, S, de Lauzon-Guillain, B. (2019). Breastfeeding initiation and duration in France: The importance of intergenerational and previous maternal breastfeeding experiences - results from the nationwide ELFE study. Midwifery, Feb, 69, 67-75.

32. Köksal, Ö, Taşçı Duran, E. (2013). Doğum Ağrısına Kültürel Yaklaşım. DEUHYO ED, 6 (3), 144-148.

33. Pınar, G, Doğan, N, Algıer, L, Kaya, N, Cakmak, F. (2009). Annelerin doğum sonu konforunu etkileyen faktörler. Dicle Tıp Dergisi, 36 (3), 184-190.

34. Yeşilçiçek Çalık, K, Kömürcü, N. (2014). SP6 Noktasına Akupresür Uygulanan Gebelerin Doğum Eylemine ve Akupresür Uygulamasına İlișkin Görüșleri. Marmara Üniversitesi Sağlık Bilimleri Enstitüsü Dergisi, 4 (1), 29-37.

35. Aktaş, S, Erkek, Z. Y. (2018). Annelerin Vajinal Doğumu Tercih Etme Nedenlerinin İncelenmesi: Bir Nitel Araștırma Örneği. Gümüşhane Üniversitesi Sağlık Bilimleri Dergisi, 7(1), 111-124.

36. Arslan, H, Karahan, N, Çam, Ç. (2008). Ebeliğin Doğası ve Doğum Şekli Üzerine Etkisi. Maltepe Üniversitesi Hemşirelik Bilim ve Sanatı Dergisi, 1 (2), 54-59.

37. Başgöl, Ș, Kızılkaya Beji, N. (2015). Doğum Eyleminin Birinci Evresinde Sık Yapılan Uygulamalar ve Kanıta Dayalı Yaklaşım. Düzce Üniversitesi Sağlık Bilimleri Enstitüsü Dergisi, 5 (2), 32 39.

38. Güleç, D, Öztürk, R, Sevil, Ü, Kazandı, M. (2014). Gebelerin Yaşadıkları Doğum Korkusu ile Algıladıkları Sosyal Destek Arasındaki İlişki. Turkiye Klinikleri J Gynecol Obst, 24 (1), 3641.

39. Kukulu, K, Öncel, S. (2009). Factors influencing women's decision to have a home birth in rural Turkey. Midwifery, 25 (1), 32-38.

40. WHO recommendations: intrapartum care for a positive childbirth experience. Geneva: World Health Organization; 2018. Licence: CC BY-NC-SA 3.0 IGO. 